\title{
Evidentiary Implications of the Speech or Debate Clause
}

On June 2, 1976, Congressman Henry Helstoski was indicted by a federal grand jury on charges of soliciting and receiving bribes in connection with an agreement to sponsor legislation for certain named aliens. ${ }^{1}$ Almost three years later, Helstoski's case remains untried, with inquiry into the merits blocked by a pretrial evidentiary ruling. ${ }^{2}$ That ruling bars all references to the past legislative acts of defendant Helstoski during the presentation of the government's case-in-chief. It excludes not only direct proof of Helstoski's performance of legislative acts but also evidence of correspondence and conversations that mention those acts. ${ }^{3}$ Both the district court that issued the order and the United States Court of Appeals for the Third Circuit that affirmed it ${ }^{4}$ held that the Constitution's speech or debate clause mandates the exclusion of such evidence in any trial of a member of Congress. 5

1. At the time of the indictment, and continuously from 1965 through 1976, Helstoski represented the Ninth Congressional District of New Jersey. Petitioner's Brief for Certiorari at 4, Helstoski v. Meanor, 576 F.2d 511 (3d Cir.), cert. granted, 99 S. Ct. 719 (1978) (No. 78-546). In the first four courts of a 12-count indictment, Helstoski was charged with conspiracy, under 18 U.S.C. $\$ 371$ (1976), and substantive violations of the federal bribery statute, $i d$. $\$ 201$. Indictment, United States v. Helstoski, No. 76-201 (D.N.J. June 2, 1976). In the remaining eight counts, Helstoski was charged with obstruction of justice, under 18 U.S.C. $\$ 1503(1976)$, and perjury, under $i d$. $\$ 1623$. Indictment, United States v. Helstoski, No. 76-201 (D.N.J. June 2, 1976).

2. See United States v. Helstoski, No. 76-201 (D.N.J. Feb. 23, 1977), aff'd, 576 F.2d 511 (3d Cir.), cert. granted, 99 S. Ct. 719 (1978) (Nos. 78-349 \& 78-546) (pretrial order).

3. Id. At a pretrial conference following the Third Circuit's decision, the district court took the exclusion another step, and stated that "it would exclude any item of evidence that .. . would afford any basis for inferring the performance of a past legislative act," including "evidence of payments of money to [Helstoski] subsequent to any legislative act," because "the jury might infer from [such proof] that [Helstoski] had fulfilled his part of the illegal bargain by performing legislative acts." Petitioner's Brief for Certiorari at 9, United States v. Helstoski, 576 F.2d 511 (3d Cir.), cert. granted, 99 S. Ct. 719 (1978) (No. 78-349).

4. United States v. Helstoski, No. 76-201 (D.N.J. Feb. 23, 1977), aff'd, 576 F.2d 511 (3d Cir.), cert. granted, 99 S. Ct. 719 (1978) (Nos. 78-349 \& 78-546) (pretrial order).

5. The speech or debate clause provides that "for any Speech or Debate in either House, they [the Members of Congress] shall not be questioned in any other Place." U.S. Consr. art. I, $\S 6, \mathrm{cl}$. 1. Prior to 1966 , only two cases involving the clause were reviewed by the Supreme Court: Tenney v: Brandhove, 341 U.S. 367 (1951), and Kilbourn v. Thompson, 103 U.S. 168 (1881). Since then, the clause has been interpreted in seven Supreme Court opinions: Eastland v. United States Servicemen's Fund, 421 U.S. 491 (1975); Doe v. McMillan, 412 U.S. 306 (1973); Gravel v. United States, 408 U.S. 606 (1972); United States v. Brewster, 408 U.S. 501 (1972); Powell v. McCormack, 395 U.S. 486 (1969); Dombrowski v. Eastland, 387 U.S. 82 (1967); and United States v. Johnson, 383 U.S. 169 (1966). There has also been increasing scholarly attention. See, e.g., Cella, The Doctrine of Legislative Privilege of Freedom of Speech and Debate: Its Past, Present and Future as a Bar to Criminal Prosecutions in the Courts, 2 SUfFolk L. REV. 1 (1968); Reinstein \& Silverglate, Legislative Privilege and the Separation of Powers, 86 HaRv. L. REv. II13 (1973). 
The traditional function of the speech or debate clause was to grant members of Congress substantive immunity for their legislative acts. ${ }^{6}$ This limited immunity was intended to protect the integrity of the legislative process by permitting members of Congress to perform their legislative functions as their consciences-and their constituenciesdictate, without fear of legal liability. ${ }^{7}$ United States $v$. Helstoski is one in a series of recent cases that has added an evidentiary dimension to the clause. ${ }^{8}$ These cases suggest that this evidentiary privilege, like the substantive immunity, is intended to protect the integrity of the legislative process. ${ }^{9}$ Yet, as Helstoski demonstrates, an expansive interpretation of the evidentiary privilege can hinder other efforts to protect that process; in particular, the evidentiary privilege can obstruct bribery prosecutions of members of Congress. In a time of great skepticism

6. The exact parameters of legislative activity are unclear. Compare Kilbourn v. Thompson, 103 U.S. 168, 204 (1881) (legislative acts are those "things generally done in a session of the House by one of its members in relation to the business before it") with Gravel v. United States, 408 U.S. 606, 625 (1972) (clause reaches matters other than speech and debate only when they are "an integral part of the deliberative and communicative processes by which Members participate in committee and House proceedings with respect to the consideration and passage or rejection of proposed legislation or with respect to other matters which the Constitution places within the jurisdiction of either House"). The Gravel definition has been criticized as unduly restrictive. See Reinstein \& Silverglate, stpra note 5 , at 1149 .

At the very least, legislative acts include voting, Powell v. McCormack, 395 U.S. 486, 502 (1969), preparing and delivering speeches in Congress, see United States v. Johnson, 383 U.S. 169, 180 (1966), participation in committee hearings and meetings, see Doe v. McMillan, 412 U.S. 306, 312 (1973), and at least some committee investigative work, see, e.g., Eastland v. United States Servicemen's Fund, 421 U.S. 491, 504-07 (1975). But see Gravel v. United States, 408 U.S. 606, 626 (1972) (criminal act that is committed while preparing for or implementing legislative act is not protected by speech or debate clause).

The term does not include, and the clause does not protect, so-called "political acts," such as intervention before government agencies on behalf of constituents, United States v. Brewster, 408 U.S. 501, 512 (1972), preparing and distributing constituent newsletters, $i d$., delivery of speeches outside of Congress, $i d$., and public distribution of arguably actionable committee reports, Doe v. McMillan, 412 U.S. 306, 314-16 (1973).

7. See, e.g., United States v. Brewster, 408 U.S. 501, 507 (1972) (purpose of speech or debate clause is "to protect the integrity of the legislative process by insuring the independence of individual legislators"); Powell v. McCormack, 395 U.S. 486, 503 (1969) (clause frees congressmen from fear of liability for representing constituents).

8. The evidentiary privilege originated with the Supreme Court's opinion in United States v. Johnson, 383 U.S. 169 (1966). Since Johnson, the evidentiary implications of the clause have been recognized repeatedly and elaborated upon both by the Supreme Court and by the lower federal courts. See, e.g., Gravel v. United States, 408 U.S. 606 (1972); United States v. Brewster, 408 U.S. 501 (1972); United States v. Dowdy, 479 F.2d 213 (4th Cir.), cert. denied, 414 U.S. 823 (1973); United States v. Garmatz, 445 F. Supp. 54 (D. Mrd. 1977).

9. See, e.g., Gravel v. United States, 408 U.S. 606, 615-16 (1972) (prohibition against questioning members of Congress regarding legislative acts during criminal trial protects legislative process); United States v. Craig, 528 F.2d 773, 778, aff'd on other grounds, 537 F.2d 957 (7th Cir.) (en banc), cert. denied, 429 U.S. 999 (1976) (purpose of evidentiary privilege same as that of substantive immunity: "preservation of the independence of the legislature"). 
regarding the ability of each branch of government to police itself, ${ }^{10}$ this discrepancy between the recognized purpose and the apparent effects of the evidentiary privilege demands that its nature and scope be reexamined.

This Note undertakes that reexamination. It suggests an interpretation of the evidentiary privilege based on the distinction between protected legislative acts and unprotected nonlegislative acts that has shaped substantive immunity under the speech or debate clause. The Note argues that reliance on that distinction in the evidentiary context would render bribery prosecutions of members of Congress feasible while protecting the legislative process from improper interference by the executive and judiciary. Thus, it would bring the purpose and effects of the evidentiary privilege into harmony.

\section{The History and Purpose of the Speech or Debate Clause}

The speech or debate clause has its roots in the doctrine of legislative immunity that evolved in England during the sixteenth and seventeenth centuries. ${ }^{11}$ The most striking difference between the American doctrine and the English doctrine from which it was derived has traditionally been the relative narrowness of the American version. Recent expansive interpretations of the evidentiary privilege depart from that historical development; in so doing, they undermine the theory behind, and threaten to frustrate the function of, the American doctrine.

\section{A. Roots in England}

During the sixteenth and seventeenth centuries, Parliament was engaged in a struggle with the Tudor and Stuart monarchs that pre-

10. See, e.g., United States v. Nixon, 418 U.S. 683 (1974) (assertion of Article II intrabranch dispute does not defeat jurisdiction of Article III courts to determine scope of executive privilege during investigation into executive corruption); Light, Finding Legislative Answers to Prevent Future GSA Fraud, 37 Cong. Q. WeEkLY ReP. 212 (1979) (proposals for congressional oversight of General Services Administration in wake of indictments and guilty pleas of agency officials on fraud and other charges); N.Y. Times, Feb. 4,1979 , at 18E, col. 1 (editorial) (deploring certain congressional committee-chairmanship appointments because of apparent conflicts of interest and other ethical problems).

11. For the most comprehensive study of the various parliamentary privileges that comprised the English doctrine of legislative immunity, see C. WITTKE, The HISTORX OF English Parlianientary Privilege (1921). Professor Wittke analyzes early developments in the conflict between the purpose of legislative immunity, protection of the people's right to representation, and one disturbing effect that legislative immunity sometimes hasimmunizing violations of other important rights. Wittke's analysis demonstrates that this conflict is as old as the doctrine itself. For other discussions of the history of legislative immunity in England, see Cella, supra note 5, at 3-16; Reinstein \& Silverglate, supra note 5 , at $1122-35$. 
cipitated its transformation from little more than an advisory council to the supreme power in England. ${ }^{12}$ Not only did Parliament acquire broad lawmaking power, but it continued to claim and exercise judicial power. ${ }^{13}$

As it fought for supremacy, Parliament sought to safeguard its proceedings by shielding its members from reprisals by various monarchs who attempted to protect their own prerogatives by punishing members for objectionable, but official, acts. ${ }^{14}$ Thus, Parliament claimed for its members immunity from criminal and civil liability for official acts, or freedom of speech and debate..$^{15}$

But Parliament's safeguards did not stop with a privilege for official acts. It also claimed a broad range of other "parliamentary privileges"16 that included immunity from civil proceedings in the common law courts. ${ }^{17}$ Parliament's claims to judicial power supplemented this immunity of its members for particular acts. Each House claimed to be the sole arbiter of its own privileges and contested the jurisdiction of

12. See C. WrTrke, supra note 11, at 12-14. See also United States v. Johnson, 383 U.S. 169, 178 (1966) (behind English speech or debate clause "lies a history of conflict between the Commons and the Tudor and Stuart monarchs"; clause was "culmination of a long struggle for parliamentary supremacy"). Parliament has thus never functioned as part of a government with equal branches. In United States v. Brewster, 408 U.S. 501, 508 (1972), the Supreme Court emphasized this difference in governmental structure, and the importance of checks and balances in the American system, as reasons for the narrower legislative immunity in the United States.

13. For several centuries, beginning at the time of the Norman Conquest, Parliament performed a variety of undifferentiated functions. The distinction between legislating and deciding cases was blurred, and both Houses of Parliament engaged in various judicial activities. See C. WiTtKe, supra note 11, at 12-14. Beginning in the sixteenth century, however, Parliament began to exercise a more clearly defined legislative power, and wielded that power in areas that had previously been within the exclusive purview of the monarchy. See id. at 23-29; Reinstein \& Silverglate, supra note 5, at 1123-26. At the same time, Parliament retained its judicial power. This combination of functions sharply differentiates Parliament from Congress. See note 21 infra.

14. The conflict between Parliament and the kings was in large part the result of an ideological split between "parliamentary privilege" and monarchical "prerogative." See M. Clarke, Parliamentary Privilege in the American Colonies 10 (1943). The breadth of parliamentary privilege can be explained, in part, by the turbulence of this transitional period. Because Parliament's position was not secure, its members needed very broad protection. Id.; C. WITTKE, supra note 11, at 43.

15. Beginning as early as 1377 , it became customary, at the opening of parliamentary scssions, for the Spcaker of the House of Commons to present to the monarch a petition that provided for the protection of parliamentary privileges. See C. WITTKE, supra note 11, at 21. It was not until 1542, however, that a claim of freedom of speech and debate was included in the Speaker's petition. Id. at 22; see Reinstein \& Silverglate, supra note 5, at 1123-29 (formal protection of freedom from liability for legislative acts essential to Parliament's cmergence as legislative body). The inclusion of a clause guaranteeing freedom of speech and debate in the English Bill of Rights, 1689, 1 W. \& M., Sess. 2, c.2, signalled a major victory for Parliament and its establishment as the highest lawmaking body in England.

16. For a comprehensive list of those privileges, see Cella, supra note $\mathbf{5}$, at 5 .

17. C. WITTKE, supra note 11 , at 16. 
the common law courts over suits that allegedly infringed those privileges; hence, civil suits involving parliamentary privileges were removed from the common law courts to Parliament itself. ${ }^{18}$ The nearly absolute nature of the English doctrine of legislative immunity was thus a product both of Parliament's struggle for supremacy and of the overlap of powers that permitted Parliament to function as a legislature and as a judicial tribunal.

\section{B. Background in America}

The scope of the immunity granted members of Congress is more modest than that claimed by Parliament during the sixteenth and seventeenth centuries. The Constitution restricts legislative immunity in the United States both through the particular provisions it includes and through the governmental structure it establishes. The Constitution's two immunity provisions are specifically contoured to safeguard proceedings in Congress: freedom from civil arrest ${ }^{19}$ provides insurance against interference with members' attendance at legislative sessions; freedom of speech and debate ${ }^{20}$ allows members to perform their legislative duties unhampered by fears of legal liability. The constitutional separation of powers between the three branches helps to insure against congressional expansion of legislative immunity beyond the scope of these two provisions. Adjudicative power is vested primarily in the courts. Members of Congress are precluded from challenging the

18. Id. at 16-17. It was not until the mid-nineteenth century, in Stockdale v. Hansard, 112 Eng. Rep. 1112 (Q.B. 1839), that the authority of the common law courts to interpret the scope of parliamentary privilege was established, and Parliament's power to divest the common law courts of jurisdiction over suits in which a claim of privilege was raised was finally extinguished, see C. WITTKE, supra note 11, at 142-54. This was well after a similar development occurred in America. See note 21 infra.

19. U.S. Consr. art. 1, $\$ 6$, cl. 1 provides that Senators and Representatives "shall in all Cases, except Treason, Felony and Breach of the Peace, be privileged from Arrest during their Attendance at the Session of their respective Houses, and in going to and returning from the same." The qualifying phrase "Breach of the Peace" includes all criminal offenses. Gravel v. United States, 408 U.S. 606, 614-15 (1972); Williamson v. United States, 207 U.S. 425, 446 (1908). Members of Congress are therefore protected only from civil arrest. See 408 U.S. at 614-15; 207 U.S. at 446.

20. The speech or debate clause was adopted by the Constitutional Convention with little discussion and no opposition. See Cella, supra note 5, at 14-15; Reinstein \& Silverglate, supra note 5 , at 1135-40. Only two proposals to modify the clause were put forth at the convention. One was that of William Pinckney. See note 21 infra. The other came from James Madison, who suggested that the scope of the clause be specifically delineated. That proposal was rejected. Madison himself later agreed that a functional approach to the privilege would better accomplish its purpose. Reinstein \& Silverglate, supra note 5, at 1139-40. The creation of an evidentiary privilege is one manifestation of this functional approach. 
courts' jurisdiction to decide the constitutionality of a suit when a claim of congressional privilege is raised. ${ }^{21}$

The task of defining the bounds of legislative immunity is thus entrusted to judges, whose difficult job it is to ensure that legislative privileges are broad enough to protect the legislative process, but not so broad as to frustrate the Framers' intention of withholding from members of Congress the kind of near-absolute personal immunity once claimed by Parliament. For unlike its English ancestor, the American doctrine of legislative immunity attempts to distinguish between protecting legislators and protecting the legislative process. ${ }^{22}$ This commitment to process protection is reflected in two case-law developments. First, in defining the reach of the speech or debate clause's substantive immunity, courts have distinguished between protected and unprotected activity. Second, they have recognized a speech or debate clause evidentiary privilege.

The substantive immunity protects all legislative acts, not only "speech or debate." 23 It does not protect nonlegislative acts, even those that have some nexus to legislative acts, such as distributing newsletters that inform constituents about legislative activities ${ }^{24}$ or receiving illicit payments for agreeing to perform legislative acts. ${ }^{25}$ An extension

21. Congress possesses limited adjudicative power under the Constitution's impeachment provisions and as part of its authority to control its own proceedings and to discipline its members. See U.S. Const. art. $1, \S 2, \mathrm{cl} .5, \S 3, \mathrm{cl} .6, \S 5, \mathrm{cls}$. 1 \& 2 . However, these exceptions to the general rule of separation of powers do not authorize Congress to hear civil suits against its members, or to try them for criminal offenses. See Kilbourn v. Thompson, 103 U.S. 168, 182 (1881); cf. United States v. Brewster, 408 U.S. 501, 518-20 (1972) (institutional difficulties and potential dangers of trials of congressmen by their colleagues). Nor do they prevent Article III courts from entertaining suits against members of Congress. United States ex rel. Hollander v. Clay, 420 F. Supp. 853, 856 (D.D.C. 1976). At the Constitutional Convention, William Pinckney suggested that Congress, not the courts, be empowered to judge the scope of legislative immunity. That suggestion was rejected. See Cella, supra note 5, at 14-15. The Framers chose instead to separate legislative and adjudicative power between two co-equal branches of government. Their choice was motivated, in part, by concern about the expansion of legislative power in America. See The Federalist No. 48 (J. Madison); cf. M. Clarke, supra note 14 (abuses of privileges by members of colonial assemblies, who had claimed immunity as broad as that claimed by members of Parliament).

22. See, e.g., Eastland v. United States Servicemen's Fund, 421 U.S. 491, 502 (1975) (quoting United States v. Brewster, 408 U.S. 501, 507 (1972)) ("The immunities of the Spech or Debate Clause were not written into the Constitution simply for the personal or private benefit of Members of Congress, but to protect the integrity of the legislative process by insuring the independence of individual legislators.' "); Tenney v. Brandhove, 341 U.S. 367, 377 (1951) ("This Court has not hesitated to sustain the rights of private individuals when it found Congress was acting outside its legislative role. . . . Legislators are immune from deterrents to the uninhibited discharge of their legislative duty, not for their private indulgence but for the public good.")

23. See note 6 supra.

24. United States v. Brewster, 408 U.S. 501, 512.(1972).

25. Id. at 524-25. 
of substantive immunity to nonlegislative acts has been deemed unnecessary to safeguard the legislative process; ${ }^{20}$ instead, press scrutiny, public reaction, and Congress's own powers have been relied upon to safeguard that process against attempts at improper interference by suits based on nonlegislative acts. ${ }^{27}$ In addition, substantive immunity has been restricted to legislative acts in recognition of the fact that the clause both safeguards citizens' right to representation and immunizes some violations of other important rights. ${ }^{28}$ This restriction is intended to minimize the protection granted to such violations. ${ }^{29}$

The evidentiary privilege complements this substantive immunity. The legislative process could be chilled if courts permitted litigants to use evidence of legislative acts to establish liability for other acts, just as it could be chilled by the imposition of liability for legislative acts themselves. ${ }^{30}$ When the executive is the litigant, the possibility of inter-

26. See note 6 supra (citing cases).

27. Thus, although Justice White dissented in United States v. Brewster, 408 U.S. 501, 555.63 (1972), in part because he feared the potential for abuse if the exccutive were authorized to prosecute disfavored members of Congress for bribery, the majority rejected potential abuse of this kind as a valid ground for extending the scope of substantive immunity, id. at 521-25. The Court emphasized that the free press and public reaction would check such abuses, $i d$. at 523 , and noted that Congress "is not without weapons of its own and would no doubt use them if it thought the Executive were unjustly harassing one of its members," id. at 522 n.16.

28. See $i d$. at $\mathbf{5 1 6}$ (though clause "must be read broadly to effectuate its purpose," it was not intended "to make Members of Congress super-citizens, immune from criminal responsibility. In its narrowest scope, the Clause is a very large, albeit essential, grant of privilege. It has enabled reckless men to slander and even destroy others with impunity, but that was the conscious choice of the Framers.")

29. Id. Other cases also reflect this balance. See, e.g., Davis v. Passman, 544 F.2d 865 (1977), rev'd on other grounds, 571 F.2d 793 (5th Cir.) (en banc), cert. granted, 99 S. Ct. 308 (1978) (No. 78-5072) (member of Congress not immune from suit for discriminatory hiring practices; such immunity not required to achieve purpose of clause); Hentoff v. Ichord, 318 F. Supp. 1175 (D.D.C. 1970) (republication of congressional committee report that infringes First Amendment rights and that on its face contradicts any assertion of valid legislative purpose not protected).

30. Evidentiary privileges are intended to insulate certain relationships and processes from outside interference and thereby promote unfettered communication and action. They are manifestations of a general belief that evidentiary rules have an impact not only on the course of a trial, but also on behavior outside the courtroom. Cf. Mapp v. Ohio, 367 U.S. 643 (1961) (suppressing evidence seized in violation of Fourth Amendment; goal is to deter police misconduct); Leff, Law and, 87 YALE L.J. 989 (1978) (interaction between rules governing judicial proceedings and life outside courtroom).

The speech or debate clause's evidentiary privilege insulates the legislative process by providing both a limited guarantee of confidentiality and an exclusionary rule. Some cases have challenged the proposition that the evidentiary privilege serves or should serve a need for confidentiality. See, e.g., In re Grand Jury Investigation, 587 F.2d 589, 597 (3d Cir. 1978) (evidentiary privilege not designed to foster secrecy in legislative process; democratic system has only limited tolerance for secrecy); In re Grand Jury Proceedings (Cianfrani), 563 F.2d 577, 584 (3d Cir. 1977) (evidentiary privilege frees legislative debate and action not by preventing disclosure, for most protected acts are already on public record, but by preventing evidentiary use of legislative acts in imposition of criminal 


\section{branch harassment is particularly pronounced. Recognizing this, recent decisions have established an evidentiary privilege. ${ }^{31}$}

liability). But the privilege can serve a legitimate need for confidentiality within the legislative process. Consider the following hypothetical: Senator $X$ receives a campaign contribution from the chairman of a pacifist organization during a controversial war that the Senator has supported, though hesitantly, from its beginning. His stand against federal funding for abortions is strong. Senator $Y$ favors federal support for abortions and staunchly opposes the war. Senator $X$ promises to vote against further appropriations for the war in exchange for Senator $Y$ 's promise to vote against federal support for abortions.

The evidentiary privilege protects the legislative process here in two ways. First, to compel Senators $X$ and $Y$ to testify about their arrangement in any proceeding could make them wary of making such compromises, and thus chill a legitimate part of the legislative process. See generally R. Dahr, Pluralist Democracy in the United States 52-54 (1967) ("ethics of responsibility" in representative government require that legislators compromise in order to achieve socially desirable ends); $R$. Musgrave \& $P$. Musgrave, Public Finance in Theory and Practice 114 (2d ed. 1976) (logrolling makes legislative process more efficient by allowing intensity of feeling to be taken into account; "logrolling in the sense of vote trading on issues is a constructive factor in decision making, to be distinguished from the shady practice of 'pork-barrel' deals, which suggests a disregard of the voter interest"). Second, to permit evidence of actual votes to be used in court might cause Senator $X$ to hesitate before switching sides on the war, even in the absence of legislative compromise, and despite the fact that the clause's substantive im. munity prevents the imposition of liability for the votes themselves. He might reasonably fear that proof of his prior votes in support of the war, the pacifist's campaign contribution, and the subsequent vote in opposition to the war might form a chain of circumstantial evidence sufficient to ground a bribery prosecution.

Shielded by an evidentiary privilege, Senator $X$ could thus act without fear either that sensitive compromises might be disclosed in court or that his change of heart could be turned against him in a subsequent legal proceeding. Cf. United States v. Brewster, 408 U.S. 501, 551-63 (1972) (White, J., dissenting) (expressing concern about persuasiveness of evidence of legislative acts in bribery prosecutions and potential for executive abuse). Proof of the campaign contribution alone would not sustain a conviction, and, if the Senator had engaged in no illicit transactions and conversations, there would be no evidence to couple with the campaign contribution to support a bribery conviction.

31. See, e.g., In re Grand Jury Investigation, 587 F.2d 589 (3d Cir. 1978) (suppressing portions of congressional telephone records, regardless of fact that records did not disclose contents of conversations, on theory that records evidenced that phone conversations possibly relating to legislative proceedings occurred); United States v. Helstoski, 576 F.2d 511 (3d Cir.), cert. granted, 99 S. Ct. 719 (1978) (Nos. 78-349 \& 78-546) (barring mere reference to past legislative acts). One court, however, has rejected the Third Circuit's expansive interpretation of the evidentiary privilege. See United States v. Garmatz, 445 F. Supp. 54 (D. Md. 1977) (distinguishing direct proof of legislative acts, by means of actual copies of bills or similar evidence, and proof of conversations and correspondence that are not themselves part of legislative process but that contain references to legislative acts). Reasoning from the Supreme Court's holding in United States v. Brewster, 408 U.S. 501, 526 (1972) (taking bribe is unprotected, nonlegislative act, regardless of any nexus it may have to protected, legislative act), the Garmatz court concluded that dis. cussions that are part of a bribery transaction are unprotected, even though they may have some nexus to a legislative act. 445 F. Supp. at 64-65.

The Garmatz court distinguished the district court's decision. in Helstoski because the government there had attempted to introduce direct proof of the defendant's legislative acts and because Helstoski was charged with substantive violations of the federal bribcry statute. Garmatz was charged only with conspiracy to violate that statute. Id. The second distinction appears to be without substance in light of the Supreme Court's holding in Brewster. There, as in Helstoski, the indictment charged substantive violations of the federal bribery statute, yet the Supreme Court upheld the indictment. See United States v. Brewster, 408 U.S. 501, 525-28 (1972). 
It is difficult to define the proper scope of the evidentiary privilege in accordance with the goal of process protection. Too broad a privilege can effectively break down the historical American distinction between protecting the legislative process and shielding legislators personally. Moreover, a broad privilege can afford defendant congressmen personal, de facto immunity for nonlegislative acts that themselves impair the integrity of the legislative process. An overly broad evidentiary privilege, therefore, undermines its own function-process protectionby obstructing proceedings that serve the same purpose as the privilege itself. The most significant cases involving the evidentiary privilegeUnited States $v$. Johnson, ${ }^{32}$ United States $v$. Brewster, ${ }^{33}$ and United States $v$. Helstosk $i^{34}$-illustrate the problems that arise when the speech or debate clause collides with federal bribery and conflict-of-interest prosecutions.

\section{The Judicial Development of the Evidentiary Privilege}

The Supreme Court cases that mark the evolution of the evidentiary privilege establish that its purpose is the same as the purpose of the substantive immunity. Although the holdings of these cases are consistent with the history of the clause, their language is often ambiguous. These ambiguities have distorted lower courts' development of the privilege, and, as United States v. Helstoski demonstrates, its effects now threaten to contravene its purpose.

\section{A. United States v. Johnson}

In United States $v$. Johnson, ${ }^{35}$ the Supreme Court first recognized the evidentiary dimension of the speech or debate clause. In Johnson, the Court reviewed the conviction of a former member of Congress on seven counts of violating the federal conflict-of-interest statute and one count of conspiracy to defraud the United States. ${ }^{36}$ One part of the conspiracy charge involved Johnson's agreement to deliver, and delivery of, a speech on the floor of the House for which he received compensation disguised as a "campaign contribution" and "legal fees." 37 Roughly one half of the testimony adduced at trial was concerned with the speech and Johnson's reasons for delivering it. ${ }^{38}$ The Supreme

32. 383 U.S. 169 (1966).

33. 408 U.S. 501 (1972).

34. 576 F.2d 511 (3d Cir.), cert. granted, 99 S. Ct. 719 (1978) (Nos. 78-349 \& 78-546).

35. 383 U.S. 169 (1966).

36. See 18 U.S.C. $\S 203$ (1976); id. § 371.

37. 383 U.S. at 171-72.

38. United States v. Johnson, 337 F.2d 180, 190 (4th Cir. 1964), aff'd, 383 U.S. 169 (1966). 
Court affirmed the Fourth Circuit's reversal of Johnson's conviction, and held that because the prosecution's evidence had focused on Johnson's legislative acts and motivations, the government had violated Johnson's rights under the speech or debate clause.

The Court held that a criminal prosecution that depends upon proof of legislative acts or testimony concerning legislative motivations is barred by the evidentiary privilege ${ }^{39}$ The opinion does not distinguish between the purpose of the evidentiary privilege and the purpose of the substantive immunity. The Court's free reliance on substantive immunity precedent ${ }^{40}$ and its historical review ${ }^{41}$ suggest that both the substantive immunity and the evidentiary privilege serve the common goal of preventing interference with the legislative process. ${ }^{42}$

Johnson demonstrates the Court's concern that the use of evidence of legislative acts and inquiry into legislative motivations in the course of a judicial proceeding can force a congressman to defend or explain those acts to avoid liability both when legislative acts are the basis of the charge and when they are merely used as evidence to establish some other alleged illegality. ${ }^{43}$ The Johnson Court emphasized that a primary function of the clause is "to prevent intimidation by the executive and accountability before a possibly hostile judiciary," 44 and

39. The Court first inferred from the language of the clause that the Constitution prohibits courtroom interrogation of a member of Congress concerning his motivations for performing legislative acts. United States v. Johnson, 383 U.S. 169, 173-74 (1966). It further supported this conclusion through extensive reference to the history of the clause. Id. at 177-83.

40. See id. at 179-83.

41. See id. at 177-83.

42. In Johnson, the government contended that the defendant had not been prosecuted for his performance of a protected legislative act-making a speech-but rather for his participation in the criminal conspiracy that had allegedly preceded the delivery of the speech. Therefore, the government urged, the prosecution had not violated the speech or debate clause. Id. at 184 . The Supreme Court rejected this argument, relying heavily on the record. $I d$. at 184-85. There is thus a suggestion in the Court's opinion that the prosecution's extensive dependence on evidence of Johnson's legislative acts and motivations belied the government's claim that the defendant had not been prosecuted for a legislative act. See id. at 177, 180, 184-85. Portions of the opinion indicate a concern that, by focusing on the defendant's motivations for delivering the speech, the government had attempted to strip the speech itself of substantive immunity on the basis of improper motivation. Id. Prior cases had clearly established the impermissibility of such a prosecution. See Tenney v. Brandhove, 341 U.S. 367, 377 (1951) ("[t]he claim of an unworthy purpose does not destroy the privilege"); Coffin v. Coffin, 4 Mass. 1, 30 (1808) (malice does not strip legislative act of protection of Massachusetts Constitution's speech or debate clause).

Furthermore, the prosecution's inquiry into legislative acts and motivations had obliged the defendant to attempt to meet the government's case by establishing the legitimacy of those acts and motivations. United States v. Johnson; 383 U.S. 169, 177 (1966). Thus, the result had been the same as if the prosecution had been directly predicated on protected acts.

43. See 383 U.S. at 177.

44. Id. at 181. 
suggested that evidentiary exploration into legislative acts may exert a chilling effect on legislative behavior. ${ }^{45}$

The Court's view of the clause was consistent with its history. ${ }^{40}$ Indeed, the Court's perception of the need for an evidentiary privilege was a logical outgrowth of that history. Yet the absence of a clear definition of the relationship between the evidentiary privilege and the substantive immunity, and the Court's failure to specify the type of evidence it deemed inadmissible, left the proper scope of the evidentiary privilege unclear. ${ }^{47}$

\section{B. United States v. Brewster}

Three years after Johnson, a federal grand jury indicted former Senator Daniel Brewster for violations of the federal bribery statute ${ }^{48}$ in connection with his opposition to postage-rate legislation. The district court dismissed the indictment and ruled that Johnson prohibited "any prosecution for alleged bribery to perform a legislative act." 49 The district court's ruling was based on its conclusion that such a prosecution would entail impermissible inquiry into legislative acts and the motivations for their performance. ${ }^{50}$ The Supreme Court reversed. ${ }^{51}$

Brewster reaffirmed the principle that the speech or debate clause prohibits all prosecutions based on legislative acts, but it rejected the defendant's argument that the clause prohibits prosecutions based on nonlegislative acts merely because they have some nexus to legislative

45. See id. at $177,180-81,184-85$.

46. See pp. 1286-87 supra.

47. This problem is particularly pronounced in the Court's instructions on remand. The Court directed the elimination of "all references to this aspect of the conspiracy." United States v. Johnson, 383 U.S. 169, 185 (1966) (emphasis added). In context, "this aspect of the conspiracy" seems to refer to the portion of the conspiracy charge involving the motives behind, and performance of, legislative acts. Despite this, the Third Circuit in United States v. Helstoski, 576 F.2d 511 (3d Cir.), cert. granted, 99 S. Ct. 719 (1978) (Nos. 78-349 \& 78-546), read the Johnson remand instructions as requiring that "all references to [defendant's speech on the floor]" be eliminated, id. at 522 (insertion in original). The implications of this interpretation are discussed in note 76 infra.

48. 18 U.S.C. $\$ \S 201(c)$, (g) (1976).

49. United States v. Brewster, No. 1872-69 (D.D.C. Oct. 9, 1970), reprinted in Jurisdictional Statement of Appellant (app. A) at 8, United States v. Brewster, 408 U.S. 501 (1972).

50. See Reply Memorandum for Appellant at 26 app., United States v. Brewster, 408 U.S. 501 (1972) (quoting district court judgc) (speech or debate clause " intends to protect Senators and Congressmen from being questioned as to why ... they voted a certain way, made a certain speech in the Congress or voted a certain way in committee . . . [I] $]$ sn't the Government ... questioning Senator Brewster for his legislative actions ... That is what I am having trouble getting around." ")

51. United States v. Brewster, 408 U.S. 501,529 (1972). 
acts. ${ }^{.2}$ Since the act of taking a bribe, though it may have some nexus to a legislative act, is not itself a legislative act, the Court held that the indictment was not barred by the clause's substantive immunity. ${ }^{53}$ Moreover, the Court emphasized that immunity extends only so far as is necessary to protect the "due functioning" of the legislative process. ${ }^{54}$ Bribery, the Court said, is not only unnecessary to the "due functioning" of the legislature, it affirmatively disrupts the legislative process. ${ }^{55}$

The Court's holding was buttressed by its analysis of the proof that would be required to sustain a conviction. Both the offense of bribery and the lesser included offense of solicitation and receipt of an illegal gratuity ${ }^{57}$ were found to consist of agreements or understandings coupled with payments or promises of payments. ${ }^{58}$ Since neither offense includes legislative acts, the government's inquiry could focus on the defendant's reasons for taking the alleged bribe, not on his reasons for, or actual performance of, protected legislative acts. ${ }^{59}$ The Court carefully distinguished between inquiry into the motivations for legislative acts, the kind of inquiry Johnson had held to be impermissible, and inquiry into the motivations for nonlegislative acts. ${ }^{60} \mathrm{It}$ repeatedly and specifically emphasized that inquiry into the reasons for taking a bribe is not prohibited by the speech or debate clause. ${ }^{.1}$ Hence, the Court

52. Id, at 513-16.

53. Id. at 524-25, 528-29.

54. Id. at 516 (emphasis in original).

55. Id. at 524-25.

56. See 18 U.S.C. $\$ 201$ (c) (1976) (public official who "directly or indirectly, corruptly asks, demands, exacts, solicits, seeks, accepts, receives, or agrees to receive anything of value for himself or for any other person or entity, in return for: (1) being influenced in his performance of any official act" shall be guilty of offense).

57. See id. $\$ 201(\mathrm{~g})$ (public official who "otherwise than as provided by law for the proper discharge of official duty, directly or indirectly asks, demands, exacts, solicits, seeks, accepts, receives, or agrees to receive anything of value for himself for or because of any official act performed or to be performed by him" shall be guilty of offense).

58. See United States v. Brewster, 408 U.S. 501, 526 (1972) (under 18 U.S.C. $\$ 201$ (c) (1976), "[t]he illegal conduct is taking or agreeing to take money for a promise to act in a certain way"); 408 U.S. at 527 (under 18 U.S.C. $\$ 201$ (g) (1976), "[t]o sustain a conviction it is necessary to show that appellee solicited, received, or agreed to receive, money with knowledge that the donor was paying him compensation for an official act. Inquiry into legislative performance itself is not necessary ....")

59. The Brewster interpretation of the nature of the offense of bribery was consistent with prior case law, which made it clear that the illicit agreement or understanding, not the actual performance of the bargained-for act, is the gravamen of the offense. See, e.g., Howard v. United States, 345 F.2d 126, 128 (lst Cir.), cert. denied, 382 U.S. 838 (1965); Whitney v. United States, 99 F.2d 327,330 (10th Cir. 1938).

60. United States v. Brewster, 408 U.S. 501, 525-28 (1972).

61. See, e.g., id. at 526 (quoting United States v. Johnson, 383 U.S. 169, 185 (1966)) ("Nor is inquiry into a legislative act or the motivation for a legislative act necessary to a prosecution under this statute. ... [A]n inquiry into the purpose of a bribe 'does not draw in question the legislative acts of the defendant member of Congress or his motives for performing them.' "); 408 U.S. at 528. 
concluded, bribery prosecutions of members of Congress are not barred by the evidentiary privilege. ${ }^{62}$

Yet the portion of the Court's opinion concerned with the types of proof prohibited by the clause is ambiguous. The Court stated that the clause, as interpreted in Johnson, precludes "any showing" of the legislative acts of a defendant member of Congress. ${ }^{63}$ The Court did not specify whether all evidence that merely referred to legislative acts should be excluded, or whether only direct proof of legislative acts should be prohibited. ${ }^{64}$

Brewster's denial of substantive immunity was consistent with the history and purpose of the clause. By distinguishing between legislative and nonlegislative acts, and granting protection only to the former, the Court perpetuated the distinction that had shaped substantive immunity since the adoption of the Constitution; it thus concurred in prior judgments regarding the appropriate means for safeguarding the legislative process. ${ }^{65}$ In addition, in withholding immunity from the act of bribery, the Court emphasized that the function of the clause and the function of the federal bribery statute are one and the same: protection of the legislative process. ${ }^{66}$

Nevertheless, Brewster's unexplained use of the term "any showing" brought the problem created by Johnson to the forefront. The failure of both Johnson and Brewster to define explicitly the scope of the evidentiary privilege contributed to the expansive interpretation of that privilege put forth in United States $v$. Helstoski. ${ }^{67}$

\section{United States v. Helstoski}

In Helstoski, the Third Circuit affirmed a pretrial order forbidding the introduction of "evidence of the performance of a past legislative act on the part of the defendant, Henry Helstoski, derived from any source and for any purpose," during the presentation of the govern-

62. United States v. Brewster, 408 U.S. 501, 525-29 (1972).

63. Id. at 527 .

64. The two courts that have interpreted the phrase "any showing" disagree on its meaning. Compare United States v. Helstoski, 576 F.2d 511, 522 (3d Cir.), cert. granted, 99 S. Ct. 719 (1978) (Nos. 78-349 \& 78-546) (mere reference to legislative acts impermissible under Brewster) with United States v. Garmatz, 445 F. Supp. 54, 64 (D. Md. 1977) (Brewster bars direct proof of legislative acts; evidence of conversations and correspondence referring to such acts admissible). Only the Garmatz interpretation is consistent with Brewster's holding that the elements of the government's prima facie case under the federal bribery statute can be established without violation of the evidentiary privilege, for only that interpretation allows proof of the illicit agreement defined in Brewster as constituting one element of the offense. See note 76 infra.

65. See pp. 1285-86 supra.

66. United States v. Brewster, 408 U.S. 501, 524-25 (1972).

67. 576 F.2d 511 (3d Cir.), cert. granted, 99 S. Ct. 719 (1978) (Nos. 78.349 \& 78.546). 
ment's case-in-chief. ${ }^{8 s}$ The Third Circuit held that evidence that referred to past legislative acts would constitute "secondary evidence" of them, and would, therefore, be inadmissible. ${ }^{69}$

The government contended that it sought to introduce evidence of conversations and correspondence that referred to Helstoski's legislative acts in order to inquire into his reasons for allegedly accepting bribes, ${ }^{\text {To }}$ an inquiry that Brewster specifically held to be constitutionally permissible. ${ }^{71}$ It argued that it offered this evidence to establish that Helstoski had entered into the kind of corrupt financial transactions that Brewster had held to be unprotected. ${ }^{72}$ The government disclaimed any intention of inquiring into Helstoski's reasons for performing legislative acts. ${ }^{73}$ Finally, the prosecution argued that illicit conversations and correspondence that merely refer to legislative acts are not themselves legislative acts, and so are entitled to no protection. ${ }^{74}$

68. See United States v. Helstoski, No. 76-201 (D.N.J. Feb. 23, 1977), aff'd, 576 F.2d 511 (3d Cir.), cert. granted, 99 S. Ct. 719 (1978) (Nos. 78-349 \& 78-546) (pretrial order).

69. United States v. Helstoski, 576 F.2d 511, 522 (3d Cir.), cert. granted, 99 S. Ct. 719 (1978) (Nos. 78-349 \& 78-546).

70. Id. at 521 .

71. See United States v. Brewster, 408 U.S. 501, 526, 528 (1972).

72. United States v. Helstoski, 576 F.2d 511, 521 (3d Cir.), cert. granted, 99 S. Ct. 719 (1978) (Nos. 78-349 \& 78-546).

73. Id.

74. Id. In addition to conversations and correspondence containing references to legislative acts, the government in Helstoski offered direct proof of the defendant's performance of allegedly bargained-for legislative acts. $I d$. at 522 . The government supported this offer of proof with the argument that, inter alia, Helstoski had waived his evidentiary privilege by testifying before seven different grand juries about his legislative acts, and producing for those grand juries documentation of his legislative performance. Id. at 522-24. The Third Circuit rejected that argument. Id. at 523-24.

Although the Supreme Court has never ruled on the issue, waiver by an individual defendant congressman of his own privilege would seem to be constitutionally permissible. Because the function of the clause is to protect the integrity of the legislative process by preventing "intimidation" of individual legislators, see Gravel v. United States, 408 U.S. 606,617 (1972), a voluntary waiver would not seem to pose a threat to the purpose of the clause, see United States v. Craig, 528 F.2d 773, 780-81, aff'd on other grounds, 537 F.2d 957 (7th Cir.) (en banc), cert. denied, 429 U.S. 999 (1976); cf. Schneckloth v. Bustamonte, 412 U.S. 218 (1973) (establishing voluntariness standard for waiver of Fourth Amendment rights). However, inquiry into or testimony concerning the defendant's colleagues' legislative acts, without a separate, voluntary waiver by them, would breach their rights under the speech or debate clause. See United States v. Craig, 528 F.2d 773, 780, aff'd on other grounds, 537 F.2d 957 (7th Cir.) (en banc), cert. denied, 429 U.S. 999 (1976) (as long as independence of other members of Congress not impugned, member may waive own evidentiary privilege); Coffin v. Coffin, 4 Mass. 1, 27 (1808) (speech or debate clause rights are personal to members of legislature).

Similar concern for the institutional integrity of the legislative branch would limit the permissible scope of a statutory waiver by the entire Congress of speech or debate clause rights. A statute that would permit the executive to inquire into legislative acts would represent a delegation of authority. The Supreme Court has reserved the delegation issue twice. See United States v. Brewster, 408 U.S. 501,529 n.18 (1972); United States v. Johnson, 383 U.S. 169, 185 (1966). A delegation of broad investigatory authority would violate the separation of powers because of its potential impact on the relationship 
The Third Circuit rejected all of these arguments. In holding that the speech or debate clause precludes not only direct proof of a congressman's past legislative acts, but all references to them, the court relied on Brewster's ambiguous prohibition against "any showing" of acts protected by the clause; the court asserted that to allow the introduction of evidence referring to legislative acts would "render Brew. ster's absolute prohibition meaningless." 75

The Helstoski rule excludes much highly probative evidence and substantially hinders the prosecution of members of Congress for bribery. ${ }^{76}$ The Third Circuit's interpretation of the evidentiary privilege goes a long way toward providing de facto substantive immunity for nonlegislative activity-bribery-that is not directly protected by

between the branches. Cf. Nixon v. Administrator of Gen. Servs., 433 U.S. 425, 441.46 (1976) (power that potentially interferes with functions of another branch cannot be delegated without specific constitutional authorization); Note, Article III Constraints and the Expanding Civil Jurisdiction of Federal Magistrates: A Dissenting View, 88 YaLE L.J. 1023, 1039 n.82 (1979) (separation-of-powers problems raised by attempts to delegate elements of Congress's power to delimit Article III courts' jurisdiction to courts themselves).

75. United States v. Helstoski, 576 F.2d 511, 522 (3d Cir.), cert. granted, 99 S. Ct. 719 (1978) (Nos. 78-349 \& 78-546).

76. See pp. 1291-92 supra (government's prima facie case). Without conversations or correspondence that mention legislative acts, the government may be unable to establish a crucial link in its chain of proof. Under Helstoski, the statement "I introduced that bill; now give me the $\$ 500$ you promised" would be inadmissible because it mentions a past legislative act. The same statement redacted-"now give me the $\$ 500$ you promised"would be inadmissible for lack of probative value; the $\$ 500$ could have been promised as a legal campaign contribution, or as part of a legitimate business transaction, rather than as a bribe.

By excluding references to "past legislative acts," the Helstoski rule makes the possibility of a successful bribery prosecution turn on the luck or connivance of the defendant in timing his illicit conversations, correspondence, and compensation, and on the government's success in procuring evidence of corrupt transactions and agreements occurring before, rather than after, the performance of legislative acts. See Petitioner's Brief for Certiorari at 12-13, United States v. Helstoski, 576 F.2d 511 (3d Cir.), cert. granted, 99 S. Ct. 719 (1978) (No. 78-349) (Helstoski rule would allow introduction of "[t] $]$ his afternoon I will introduce a private immigration bill in exchange for the $\$ 500$ that you gave me," but forbid "I introduced a private immigration bill this afternoon, and I want the $\$ 500$ that you promised in exchange"). An illicit conversation that follows the performance of a legislative act is no more a part of the legislative process than an illicit conversation that precedes such performance. Cf. Doe v. McMillan, 412 U.S. 306, 314 (1973) (quoting Gravel v. United States, 408 U.S. 606, 625 (1972)) (public distribution of committee report not legislative act because not "'an integral part of the deliberative and communicative processes by which Members participate in committee and House proceedings'"); Gravel v. United States, 408 U.S. 606, 625 (1972) (private republication of committee report not legislative act because not "essential to the deliberations of the Senate"); United States v. Brewster, 408 U.S. 501, 526 (1972) ("Taking a bribe is, obviously, no part of the legislative process or function; it is not a legislative act.") At least one court has recognized this, and rejected the Helstoski rule. See United States v. Garmatz, 445 F. Supp. 54, 65 (D. Md. 1977) (determinant of admissibility is not time of illicit act sought to be proved, but whether proffered evidence constitutes direct proof of legislative act). 
the clause. Helstoski's treatment of the evidentiary privilege thus divorces it from the purpose of the speech or debate clause.

\section{Bribery Prosecutions and the Evidentiary Privilege: A Reconciliation}

The Helstoski evidentiary rule exemplifies the present dilemma in the case law. This dilemma can be resolved through an analysis that returns to the rationale of the speech or debate clause and defines the scope of the evidentiary privilege in accordance with that rationale.

In defining the scope of the clause's substantive immunity, the Supreme Court has recognized that the clause both safeguards the legislative process and immunizes some violations of important rights. ${ }^{77}$ The distinction between protected legislative acts and unprotected nonlegislative acts is designed to minimize privileged wrongdoing, while maximizing the protection afforded the legislative process. ${ }^{78}$

Thus, the shield afforded by the clause is not absolute. In fact, the American doctrine of legislative immunity is narrow enough to allow the operation of other mechanisms to protect the legislative process. These mechanisms include conflict-of-interest ${ }^{79}$ and bribery ${ }^{80}$ prosecutions. The Helstoski decision undermines this multifaceted approach to process protection; it fails to recognize that an accommodation with the federal bribery statute enhances the values served by the speech or debate clause.

The evidentiary privilege should be governed by the same principle that has limited the substantive immunity. The evidentiary privilege, like the substantive immunity, should distinguish between protecting the legislative process and shielding individual legislators by distinguishing between legislative and nonlegislative acts. ${ }^{81}$ The kind of

77. See p. 1286 supra.

78. Id.

79. See 18 U.S.C. $\$ 203$ (1976).

80. See id. $\$ 201$; United States v. Brewster, 408 U.S. 501, 524-25 (1972) (purpose of clause to "preserve the independence and thereby the integrity of the legislative process. But .. bribes, perhaps even more than Executive power, would gravely undermine legislative integrity.... Depriving the Executive of the power to investigate and prosecute and the Judiciary of the power to punish bribery ... is unlikely to enhance legislative independence.")

81. In interpreting the scope of other evidentiary privileges, the Supreme Court has repeatedly emphasized that these privileges must be carefully contoured to the achievement of their purposes, and that evidentiary privileges, as exceptions to the general rule of full disclosure in judicial proceedings, are to be narrowly construed. See Fisher v. United States, 425 U.S. 391, 403-04 (1976) ("since the [attorney-client] privilege has the effect of withholding relevant information from the factfinder, it applies only where 
conversations that the government sought to introduce in Helstoski may be no more a part of the "due functioning" 82 of the legislative process than the kind of financial transaction that Brewster declared to be unprotected..$^{83}$ The problem the Third Circuit saw with the evidence in Helstoski was not that the alleged illegal transaction in question was protected, but that the evidence in question contained references to protected acts. However, the Third Circuit failed to recognize that such mere references to legislative acts, unlike direct proof of legislative acts, do not contravene the purpose of the speech or debate clause.

Under the federal bribery statute, ${ }^{84}$ the government must show that a payment was made, or was planned to be made, and that the defendant understood that that payment was intended to have, or agreed that it was to have, some nexus to a legislative act..$^{85}$ Actual performance of the bargained-for, or compensated, act is not an element of the offense; in fact, proof of performance of a contrary act does not negate the crime. ${ }^{86}$ Therefore, a defendant congressman's conversations and correspondence referring to legislative acts would be introduced to establish not the performance of legislative acts, but the existence of an illicit agreement or understanding. Thus, they would be admitted not as "secondary evidence" of protected legislative acts, but as primary evidence of the defendant's purpose in accepting the bribe.

The admission of such evidence would be analogous to the admission of statements falling within the state of mind exception to the hearsay rule $^{87}$ when the declarant's state of mind is material to the case, but the facts referred to in the hearsay statements are irrelevant.. ${ }^{s 8}$ Such

necessary to achieve its purpose”); United States v. Nixon, 418 U.S. 683, 710 (1974) (“Whatever their origins, these exceptions to the demand for every man's evidence are not lightly created nor expansively construed, for they are in derogation of the search for truth.")

82. United States v. Brewster, 408 U.S. 501, 516 (1972) (emphasis in original).

83. The government's offer of proof in Helstoski has been placed under seal, see Petitioner's Brief for Certiorari at 7 n.4, United States v. Helstoski, 576 F.2d 511 (3d Cir.), cert. granted, 99 S. Ct. 719 (1978) (No. 78-349). Precise characterization of the actual conversations and correspondence involved is therefore impossible. The purpose of this Note is to provide an analysis that can govern the admissibility of evidence in bribery cases in accordance with the purposes of the speech or debate clause, and not to apply that analysis to the government's offer of proof in Helstoski.

84. 18 U.S.C. $\$ 201$ (1976).

85. See United States v. Brewster, 408 U.S. 501, 525-29 (1972).

86. Id.

87. FED. R. Evin. 803(3).

88. The admission of such conversations and correspondence would thus be altogether different from the admission of the hearsay statement in Shepard v. United States, 290 U.S. 96 (1933) (alternative holding) (statements of memory or belief are not admissible under state of mind exception when fact remembered or believed is gravamen of offense charged), or United States v. Annunziato, 293 F.2d 373 (2d Cir.), cert. denied, 368 U.S. 919 (1961) (hearsay declaration of intention embodying mention of past event admissible 
statements are admitted not as "secondary evidence" of those facts, but rather as primary evidence of the declarant's understanding. ${ }^{39}$

The use of evidence of conversations and correspondence containing references to legislative acts is consistent with the history and purpose of the clause. The use of such evidence would not be equivalent to the use of evidence of legislative acts themselves in the imposition of criminal liability. ${ }^{90}$ It would not entail inquiry into legislative motivations. It would not, therefore, call upon a defendant congressman to explain or justify his legislative acts or motivations to the executive, in a judicial forum. ${ }^{91}$ Thus, admission of this evidence would perpetuate the distinction between protected legislative acts and unprotected nonlegislative acts that has traditionally implemented the purpose of the speech or debate clause.

\section{Conclusion}

In the history of the doctrine of legislative immunity, one theme recurs: the purpose of that doctrine is to protect the integrity of the legislative process. Realizing that purpose is difficult. No simple rule

though past event, which motivated plan, relevant to government's case). In both cases, the facts referred to in the hearsay statements were elements in the government's prima facie case. For that reason, Shepard's conviction was reversed by the Supreme Court, and Annunziato has been criticized, see J. WeINSTEIN \& M. BerGer, WeINSTEIN's Evidence f $803(3)[05]$, at 116-17 (1978). By contrast, the defendant's performance of a legislative act is not an element of, or even relevant to, the government's prima facie case under the federal bribery statute, so the admission of the type of conversation excluded by the Third Circuit in Helstoski would not be objectionable.

89. See, e.g., United States v. Adcock, 558 F.2d 397, 403-04 (8th Cir.), cert. denied, 434 U.S. 921 (1977) (in prosecution for extortion, victim's testimony regarding defendant's out-of-court threats admissible to prove victim's state of mind, but not to prove truth of hearsay declarations); Oberman v. Dun \& Bradstreet, Inc., 507 F.2d 349 (7th Cir. 1974) (in libel action, hearsay declaration indicating reason for credit denial admissible to prove lender's state of mind, but not to establish that libelous event said to have motivated denial actually occurred).

90. Although a jury might infer the performance of legislative acts from conversations and correspondence that mention them, the danger of prejudice or confusion created by such an inference could be minimized by explicit jury instructions on the irrelevance of legislative performance to the offense charged. Such an instruction could be given both at the time the evidence is introduced and during the final jury charge. Cf. United States v. Adcock, 558 F.2d 397, $403-04$ (8th Cir.), cert. denied, 434 U.S. 921 (1977) (potential prejudice created by admission of hearsay statements under state-of-mind exception cured by jury instructions).

91. Although United States v. Johnson, 383 U.S. 169 (1966), forbids the use of evidence of the performance of legislative acts to prove illegal agreements, nothing in Johnson suggests that evidence of those agreements that incidentally mentions legislative acts should be barred. The introduction of such evidence would not call upon a defendant congressman to justify his legislative behavior; it would call upon him to justify his extralegislative agreements and financial transactions, and would therefore not contravene Johnson. 
has been developed to determine what events in a court of law are apt to shape events in Congress impermissibly. However, one workable distinction has emerged in the area of substantive immunity: legislative acts are protected; nonlegislative acts are not. Departure from that distinction in the evidentiary context breaks down the barrier between protecting the legislative process and protecting individual legislators.

The rule that should govern the interpretation of the evidentiary privilege is that which has defined the scope of the substantive immunity: proof of legislative acts should not be allowed; proof of nonlegislative acts, regardless of their nexus to legislative acts, should be permitted. A return to this basic distinction would resolve the tension that now exists between the purpose and effects of the evidentiary privilege. 